\title{
Removal of anthropogenic lead pollutions by a potent Bacillus species AS2 isolated from geogenic contaminated site
}

\author{
A. Cephidian ${ }^{1}$ A. Makhdoumi ${ }^{2}$ M. Mashreghi ${ }^{2}$ M. H. Mahmudy Gharaie ${ }^{1}$
}

Received: 14 February 2016/Revised: 20 April 2016/Accepted: 18 May 2016/Published online: 2 June 2016

(C) Islamic Azad University (IAU) 2016

\begin{abstract}
A total of 422 bacterial isolates were obtained from the lead $(\mathrm{Pb})$ ore in north-eastern Iran. The $\mathrm{Pb}$ tolerances of these strains were studied using microbroth serial dilution approach and 35 strains could grow up to $3250 \mathrm{ppm} \mathrm{Pb}$ concentration. Of these strains, 10 of them represented qualitatively high levels of $\mathrm{Pb}$ adsorption and were selected for quantitative studies. Strain AS2 which is phylogenetically related to genus Bacillus showed the highest level of $\mathrm{Pb}$ remediation. The effects of different factors, including $\mathrm{pH}$, initial $\mathrm{Pb}$ concentration, temperature and inoculum size, were studied on the remediation process. $\mathrm{Pb}$ remediation capacity was reached at $74.5 \mathrm{mg} / \mathrm{g}$ $(99.5 \%$ of initial $\mathrm{Pb})$ at $\mathrm{pH} 4.5$, temperature $30^{\circ} \mathrm{C}$, inoculum size $1.0 \%(\mathrm{v} / \mathrm{v})$ and an initial $\mathrm{Pb}$ concentration of $500 \mathrm{ppm}$ after $24 \mathrm{~h}$. Pb desorption capacity of strain was $66 \%$. The novel isolate could remove $98 \%$ of $\mathrm{Pb}$ from the contaminated industrial wastes after $24 \mathrm{~h}$. Pb uptaking to the cell surface was proven using scanning electron microscopic micrograph and energy-dispersive X-ray spectroscopy analysis. Most $\mathrm{Pb}$ removal efficiency was observed in the active cell culture as compared to the inactive cell and extracellular polymeric substances. The novel strain represents a good candidate for removal of environmental anthropogenic $\mathrm{Pb}$ pollutions.
\end{abstract}

A. Makhdoumi

a.makhdomi@um.ac.ir

1 Department of Geology, Faculty of Science, Ferdowsi University of Mashhad, Mashhad, Iran

2 Department of Biology, Faculty of Science, Ferdowsi University of Mashhad, P.O. Box: 91775-1436, Mashhad, Iran
Keywords Anthropogenic · Bioremediation - Geogenic · Lead $(\mathrm{Pb})$

\section{Introduction}

Lead $(\mathrm{Pb})$ is a non-essential heavy metal. It causes serious health hazards, that is, permanent brain damage, learning disabilities, hearing loss, anaemia, insomnia, headache, dizziness, irritability, weakness of muscles, renal damages and heart disease (Naseem and Tahir 2001). Industrial activities, such as production of batteries, pigments and metal smelting, as well as manufacturing of products, such as $\mathrm{Pb}$ arsenate insecticides or $\mathrm{Pb}$ water pipes, are the main anthropogenic sources of $\mathrm{Pb}$ (Jarosławiecka and Piotrowska-Seget 2014; Ismail et al. 2013). Accordingly, large volumes of $\mathrm{Pb}$-containing wastes from these industries are introduced into environments. To protect ecosystems, wastewaters must be treated to reduce $\mathrm{Pb}$ to below $0.05-0.10 \mathrm{ppm}$ before discharging into the environment (Sağ et al. 1995). Different physical and chemical methods have been applied to treat $\mathrm{Pb}$-containing wastes. These methods include adsorption, flotation, ion exchange, membrane filtration and precipitation (Chen et al. 2009; Kabbashi et al. 2009; Landaburu-Aguirre et al. 2009; Zhang et al. 2009). The physico-chemical methods are generally expensive, so the need for hazardous reagents produces other toxic chemicals and requires long treatment time. The biological systems apply a process called bioremediation to protect environments from toxic effects of hazardous components. Since the elemental form of $\mathrm{Pb}$ is toxic, it cannot be degraded or transformed (biotransformation/biodegradation) into a less dangerous material. However, the living systems (like bacteria) can precipitate bioavailable soluble and toxic $\mathrm{Pb}$ to insoluble forms 
(biosorption) and reduce drastically its availability and toxicity. The major advantages of the biosorption approach are its high effectiveness in reducing the heavy metal ions and the low cost of the process (Macek and Mackova 2011). Various groups of microorganisms like Bacillus cereus, Arthrobacter species, Corynebacterium species (Roane and Kellogg 1996; Trajanovska et al. 1997; Zanardini et al. 1997), Pseudomonas marginalis, Pseudomonas vesicularis, Enterobacter species (Hasnain et al. 1993; Trajanovska et al. 1997), Saccharomyces cerevisiae and Penicillium species (Chen and Wang 2007; Sun and Shao 2007) were reported for their ability to remediate $\mathrm{Pb}$ contaminations using the adsorption method.

Heavy metals like $\mathrm{Pb}$ are found in the environments as the natural sources (geogenic) of parent rocks and metallic minerals (metalliferous ores) (Sparks 2005). The long-time contacts of microbial populations with this element in the contaminant regions result in the enrichments of resistant strains by the act of natural selection. Accordingly, these indigenous species are appropriate candidates for bioremediation of anthropogenic (Human made) pollutions. This study describes the isolation of $\mathrm{Pb}$-tolerant and absorbing bacteria from $\mathrm{Pb}$ ore, and the influence of various biosorption-related variables, such as $\mathrm{pH}$, inoculums size, temperature and initial $\mathrm{Pb}$ concentration, was studied on the selected strain. The ability of novel strain to remediate industrial $\mathrm{Pb}$-containing wastes was also taken into account.

\section{Materials and methods}

\section{Site description, samples collection and analysis}

Samples were collected from different sites of Tarik Darreh $\mathrm{Pb}$ Ore in north-eastern Iran $\left(35^{\circ} 21^{\prime}-35^{\circ} 28^{\prime} \mathrm{N}, 60^{\circ} 40^{\prime}-\right.$ $60^{\circ} 49^{\prime} \mathrm{E}$ ). The samples including soil, water and sediment were collected in sterile plastic containers and kept in the dark at an environmental temperature for a few hours before being analysed in the laboratory. Anions and cations were analysed using titration and atomic absorption methods (atomic absorption spectroscopy, AAS), respectively (Maiti 2004; Saad et al. 1998). Pb concentration was analysed using AAS-7000 (Shimadzu, Japan).

\section{Culture media and growth conditions}

Bacteria were isolated under aerobic conditions on LuriaBertani (LB) agar (Merck). The $\mathrm{pH}$ of the medium was adjusted at $\mathrm{pH} 5.0$ by $2 \mathrm{M} \mathrm{HNO}_{3}$. All samples were serially diluted up to $10^{-6}$ and plated by spreading method. The plates were incubated at different temperatures of 20,30 and $40{ }^{\circ} \mathrm{C}$ for 2 weeks. Pure isolates were obtained after successive cultivation. The isolates were maintained on the slant LB medium at $4{ }^{\circ} \mathrm{C}$ and LB broth medium supplemented with $30 \%(\mathrm{v} / \mathrm{v})$ glycerol at $-80{ }^{\circ} \mathrm{C}$ for short and long preservations, respectively.

\section{Minimum inhibitory concentration (MIC) determination}

Since $\mathrm{Pb}$ chemically precipitates in alkaline condition (Leung et al. 2001), the pH was adjusted to acidic condition $(\mathrm{pH}<5.0)$ with $2 \mathrm{M} \mathrm{HNO}_{3}$ in all $\mathrm{Pb}$ relative experiments. MIC determination was conducted in LB liquid medium by broth microdilution method. It was performed with 96-well, round-bottom microtiter plate. The final volume of wells was $200 \mu \mathrm{l}$. Each plate included positive control (bacteria without $\mathrm{Pb}$ ), negative control (medium only) and serial twofold dilutions of $\mathrm{Pb}$ in $\mathrm{LB}$ medium. Bacterial inoculum was produced from mid-log culture in $\mathrm{Pb}$-free $\mathrm{LB}$ medium. After the addition of a $100 \mu \mathrm{l}$ inoculum containing $2 \times 10^{6}$ cells $/ \mathrm{ml}$ to $\mathrm{Pb}$-containing positive control wells, the plates were incubated at $30{ }^{\circ} \mathrm{C}$. Bacterial growth was determined by measuring the turbidity at $600 \mathrm{~nm}$. The lowest concentration of $\mathrm{Pb}$ which inhibited the bacterial growth was determined as the MIC of the isolate.

\section{Quantitative and qualitative screening for Pb-absorbing bacteria}

In order to evaluate the biosorptive potential of $\mathrm{Pb}$-resistant bacteria, a rapid agar screening method was used, which was introduced by Pümpel et al. (1995). Briefly, bacterial strains were punctually inoculated in $\mathrm{Pb}$-free $\mathrm{LB}$ agar and incubated for $48-72 \mathrm{~h}$ at $30{ }^{\circ} \mathrm{C}$. The petri dishes were then overlaid by soft agar containing $500 \mathrm{ppm} \mathrm{Pb}$ and incubated for $24 \mathrm{~h}$ at $30^{\circ} \mathrm{C}$. Afterwards, $\mathrm{Pb}$ removal from solid media by microorganisms was visualized by exposing each plate to $\mathrm{H}_{2} \mathrm{~S}$ vapours, which was generated in situ by reacting sodium sulphide with hydrochloric acid in a stoichiometric ratio. Precipitation of lead sulphide $(\mathrm{PbS})$ and halo formation around the colonies were considered for $\mathrm{Pb}$ biosorption capacity. For quantitative measurement of $\mathrm{Pb}$ adsorption, the liquid LB medium was supplemented with $100 \mathrm{ppm} \mathrm{Pb}$ concentration. Cultures were grown in $150 \mathrm{rpm}$ at $30{ }^{\circ} \mathrm{C}$ for $24 \mathrm{~h}$. After the incubation, supernatant was collected and $\mathrm{Pb}$ absorption was determined using AAS. Cultures containing $100 \mathrm{ppm} \mathrm{Pb}$ without inoculum were applied as negative control.

\section{Factors affecting removal process}

To understand the effects of various conditions on $\mathrm{Pb}$ removal, growth conditions or chemical components were varied one at a time. Organisms were cultured in $25 \mathrm{ml} \mathrm{LB}$ 
medium containing $\mathrm{Pb}$ as $\mathrm{PbNO}_{3}$ in 100-ml Erlenmeyer flasks incubated aerobically at $150 \mathrm{rpm}$ in an orbital shaker. These variables consisted of various $\mathrm{pH}$ of the medium which was adjusted to $\mathrm{pH} 3.0,3.5,4.0,4.5$ and 5.0; initial $\mathrm{Pb}$ concentrations of 50, 100, 200, 300, 400, 500, 600 and $700 \mathrm{ppm}$; different incubation temperatures of 20, 25, 30, 35 and $40{ }^{\circ} \mathrm{C}$; various inoculum sizes of $0.5,1.0,3.0,5.0$ and $7.0 \%(\mathrm{v} / \mathrm{v})$; and incubation time up to 36- and 2-h intervals. Residual $\mathrm{Pb}$ was measured using AAS.

Biological removal efficiency (BRE) and biological removal capacity (BRC) were calculated as shown in the following formula:

$$
\begin{aligned}
\operatorname{BRE}(\%)= & \text { Primary lead concentration }(\text { non inoculated }) \\
& - \text { Residual lead concentration }(\text { inoculated }) / \\
& \text { Primary lead concentration }(\text { non inoculated }) \times 100
\end{aligned}
$$

$\mathrm{BRC}(\mathrm{mg} / \mathrm{g})=$ Primary lead concentration (non inoculated)

- Residual lead concentration (inoculated) /

Bacterial biomass (dry weight)

Each experiment was carried out in three independent batches in triplicates (nine replications). The standard error of the mean was calculated and was shown as error bars on the figures. One-way analysis of variance (ANOVA) and Tukey's honest significant difference (HSD) test were performed using Statistical Package for Social Science (SPSS) ver. 16 software (IBM Co).

\section{Comparing active-inactive cells and extracellular polymeric substances (EPS) in removal process}

Fresh culture media of selected strain were prepared and divided into three parts. Two parts were inactivated by autoclave and treatment by $1 \mathrm{mM}$ sodium azide (Johnson et al. 2007), respectively. All the autoclaved (inactive), sodium azide treatment (inactive) and living cells (active) were harvested by centrifugation at $7500 \mathrm{~g}$ for $10 \mathrm{~min}$. To determine whether bacterial exopolysaccharides are involved in bioremediation, the EPS of the bacterial culture was extracted as described by Zhang et al. (2002). The ability of active and inactive cells as well as extracted exopolysaccharide to uptake $\mathrm{Pb}$ was measured as mentioned in "Quantitative and qualitative screening for $\mathrm{Pb}$ absorbing bacteria" section.

\section{Scanning electron microscopic (SEM) and energy- dispersive X-ray spectroscopy (EDS) analysis}

Samples for SEM studies were harvested from LB liquid culture containing $500 \mathrm{ppm}$ concentration of $\mathrm{Pb}$ at the optimum condition. Cells pellets were freeze-dried and coated with gold using a sputter coater (EmscopeSc 500). SEM analysis was performed using a LEO.1450.VP/REM (Oberkochen-Zeiss, Germany). EDS elemental analysis was carried out on non-treated bacterial cells as well as bacterial cells interacted with $\mathrm{Pb}$ using an ESEM FEI Quanta 200, high-resolution electron microscope.

\section{Measurement of $\mathrm{Pb}$ desorption capacity}

Bacterial cells were harvested from adsorption experiments and washed with distilled water to remove unbanned $\mathrm{Pb}(\mathrm{II})$. The biomass was transferred to desorbent solution containing $\mathrm{HNO}_{3}, \mathrm{Ca}\left(\mathrm{NO}_{3}\right)_{2}$ and ethylenediaminetetraacetic acid (EDTA; 0.10 and $0.01 \mathrm{M}$, respectively), and the solution was shaken for $18 \mathrm{~h}$. The biomass was collected and analysed to determine the concentration of $\mathrm{Pb}$ (II) after desorption (Deng et al. 2007). Desorption capacity was calculated as follows:

Desorption capacity $(\%)=$ Amount of desorbed lead $/$

Amount of adsorbed lead $\times 100$

\section{Removal of anthropogenic $\mathrm{Pb}$ contamination in batch fermentation}

Remediation of $\mathrm{Pb}$-contaminated wastes from local batteries and dye industries was carried out in a $1 \mathrm{~L}$ batch fermentation system with waste $\mathrm{Pb}$ added at $500 \mathrm{ppm}$ concentration to the optimal removal of LB culture. Residual $\mathrm{Pb}$ was measured using AAS.

\section{Molecular identification of the strain}

The genomic DNA of the strain was extracted using DNA extraction kit (Thermo scientific, Lithuania) according to the manufacturer's recommended procedure, and the $16 \mathrm{~S}$ rRNA gene was amplified using the bacterial universal primers 27F and 1492R (Lane et al. 1985). Amplification reactions contained $1.5 \mu \mathrm{l}$ of each primer, $1 \mu \mathrm{l}$ of $10 \mathrm{mM}$ deoxynucleotide (dNTP), $5 \mu$ polymerase chain reaction (PCR) buffer, $1.5 \mu \mathrm{l}$ of $50 \mathrm{mM} \mathrm{MgCl} 2,4 \mu \mathrm{l}$ template DNA, $0.25 \mu \mathrm{l}$ DNA polymerase and $35.25 \mu \mathrm{d}_{2} \mathrm{O}$, in a final volume of $50 \mu \mathrm{l}$. The following conditions were used in the amplification of $16 \mathrm{~S}$ rRNA gene: $94{ }^{\circ} \mathrm{C}$ for $2 \mathrm{~min}$, followed by 30 cycles of $94{ }^{\circ} \mathrm{C}$ for $60 \mathrm{~s}, 55{ }^{\circ} \mathrm{C}$ for $60 \mathrm{~s}$ and $72{ }^{\circ} \mathrm{C}$ for $60 \mathrm{~s}$, with a final 7 -min extension at $72{ }^{\circ} \mathrm{C}$. PCR products were purified with the DNA purification kit (Bioneer, South Korea), according to the manufacturer's protocol. The sequencing was conducted on an ABI 3730XL DNA sequencer at Macrogen (Seoul, South Korea). 


\section{Results and discussion}

\section{Chemical characterization of sample and isolation of bacteria}

Several water, soil and sediment samples from Tarik Darreh Ore were obtained and used in this study ( $\mathrm{pH}$ of the samples was neutral to slightly alkaline (7.3-7.8). The $\mathrm{Pb}$ concentration in the soil samples was $400 \mathrm{mg} \mathrm{kg}^{-1}$. Concentration of major cations and anions was as follows $(\mathrm{mg} /$ L): $\mathrm{Ca}^{2+}(80), \mathrm{Mg}^{2+}$ (22.4), $\mathrm{Na}^{+}$(47.5), $\mathrm{K}^{+}$(5.2), $\mathrm{HCO}_{3}{ }^{-}$ (317.6), $\mathrm{SO}_{4}{ }^{2-}$ (53.4) and $\mathrm{Cl}^{-}$(32.8). The LB agar-isolating medium yielded high numbers of colonies, and the range was $2.5 \times 10^{6}-4.4 \times 10^{6} \mathrm{CFU} / \mathrm{ml}$. A total of 422 pure isolates were obtained by successive cultivation. These strains were characterized as Gram-positive cocci (33 isolates), Gram-negative cocci (10 isolates), Grampositive bacilli (285 isolates) and Gram-negative bacilli (94 isolates).

\section{MIC determination and selection of Pb-absorbing bacteria}

A total of 36 strains could not tolerate the minimum amount of $\mathrm{Pb}$ and only grew in the absence of $\mathrm{Pb}$. The MIC for other strains was as follows: $100 \mathrm{ppm}$ (40 strains), $500 \mathrm{ppm}$ (34 strains), $1000 \mathrm{ppm}$ (48 strains), $1500 \mathrm{ppm}$ (79 strains), $2000 \mathrm{ppm}$ (97 strains) and $3000 \mathrm{ppm}$ (52 strains). A total of 35 strains showed the highest $\mathrm{Pb}$ tolerance and could grow up to $3125 \mathrm{ppm}$ initial $\mathrm{Pb}$ concentration. Among the last group, eight strains showed the highest qualitative $\mathrm{Pb}$ absorption (Fig. 1) and were selected for further quantitative analysis. One strain was designated as AS2 that uptakes remarkable amount of initial $\mathrm{Pb}$

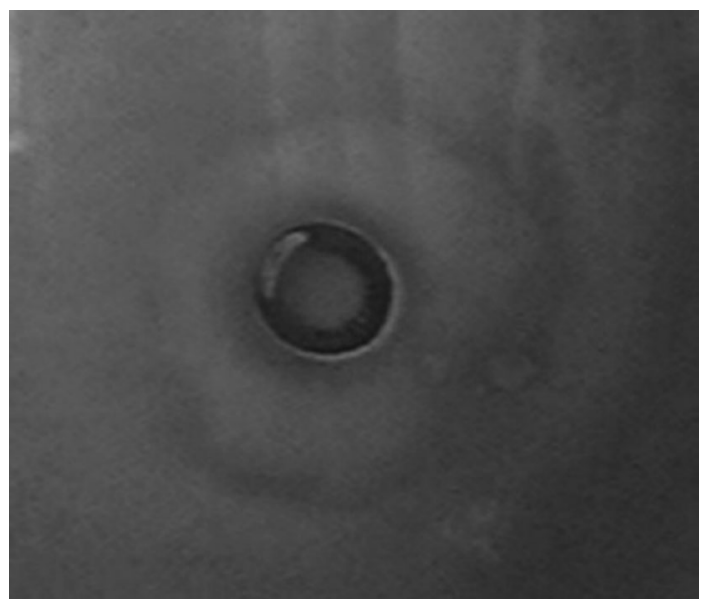

Fig. 1 Assay of $\mathrm{Pb}$ absorption activity on plate with solid isolation medium supplemented with $\mathrm{Pb}(500 \mathrm{ppm})$. Clearing zone of $\mathrm{Pb}$ absorption formed around the colony concentration (BRE $87 \%$; BRC $109 \mathrm{mg} / \mathrm{g}$ ) and was selected for optimization studies. Geogenic contaminated sites were reported to be good sources for heavy metal tolerance microbes with potential applications in bioremediation. Arsenic-, cadmium-, copper- and zinc-resistant bacteria were isolated from gold, lead-zinc, copper and silver mine soils, respectively ( $\mathrm{Li}$ et al. 2013; PiotrowskaSeget et al. 2005; Zhu et al. 2012). Heavy metal tolerance of the microbial community in these environments could be acquired by genetically tolerance elements (genes involving in metal resistance are mostly presented in plasmids) and shift in species composition (Hu et al. 2007). More than $90 \%$ of bacterial strains obtained from $\mathrm{Pb}$ ore in this study could tolerate at least $100 \mathrm{ppm} \mathrm{Pb}$. There are a wide range of $\mathrm{Pb}$ tolerances in scientific reports: Pseudomonas aeruginosa ASU 6a (Gabr et al. 2008) was able to survive under the maximum range of $\mathrm{Pb}$ concentration up to 500 ppm, Entrococcus faecum $\mathrm{Pb} 12$ tolerates $800 \mathrm{ppm} \mathrm{Pb}$ (Bhakta et al. 2012), and Achromobacter species TL-3 isolated from activated sludge samples tolerates $1500 \mathrm{ppm}$ $\mathrm{Pb}$ in Luria broth medium (Batta et al. 2013). The novel strain AS2 which was isolated from $\mathrm{Pb}$ ore in this study showed the maximum MIC to be higher than previous report and could survive up to $3125 \mathrm{ppm} \mathrm{Pb}$.

\section{Factors affecting removal process}

As shown in Fig. 2, a biological removal efficiency of $100 \mathrm{ppm}$ initial $\mathrm{Pb}$ was $87,90,95,90$ and $86 \%$ at $\mathrm{pH} 3.0$, $3.5,4.0,4.5$ and 5.0, respectively. Bacterial growth was increased as the $\mathrm{pH}$ of the medium increased. $\mathrm{Pb}$ removal capacities for the selected strain were $(\mathrm{mg} / \mathrm{g})$ : $13.1,13.6$, 14.4, 13.5 and 12.8 at $\mathrm{pH} 3.0,3.5,4.0,4.5$ and 5.0, respectively. $\mathrm{Pb}$ adsorption was best at $\mathrm{pH} 4.0(p<0.05)$ for strain AS2, and this $\mathrm{pH}$ was applied in the following experiments. Concentration of hydrogen ion $(\mathrm{pH})$ has significant influence on $\mathrm{Pb}$ removal capacity. Under $\mathrm{pH}$ condition of above 6, the accumulation of hydroxyl group $\left(\mathrm{OH}^{-}\right)$results in the chemical precipitation of $\mathrm{Pb}$ as $\mathrm{Pb}(\mathrm{OH})_{2}$ and misunderstanding the bioremoval capacity. In contrast, high acidic condition $(\mathrm{pH}<2)$ decreased the removal capacity as a result of competition for negatively charged binding sites between heavy metal cation and protons $\left(\mathrm{H}^{+}\right)$. However, the optimal $\mathrm{pH}$ condition is also depending on the metal-accepting groups (if any) on the bacterial surface. For example, phosphoryl groups are mainly in unprotonated form already at $\mathrm{pH} 2(\mathrm{pKa} \approx 1.5)$, so bacteria with this uptaking groups can remove $\mathrm{Pb}$ at lower pH (Halttunen et al. 2007). Strain AS2 removed maximum $\mathrm{Pb}$ at $\mathrm{pH} 4.5$ and postulated that it applied binding groups to higher $\mathrm{pKa}$ than phosphoryl groups. Strain AS2 adsorbed 91, 92, 95, 96, 97, 98, 93 and $85 \%$ of $\mathrm{Pb}$ at the initial concentrations of 50,100, 200, 300, 400, 

concentration, temperature, inoculum size and incubation time on $\mathrm{Pb}$ removal efficiency (grey columns/line) and growth (black columns/line) of strain Bacillus species AS2
Fig. 2 Effects of $\mathrm{pH}, \mathrm{Pb}$
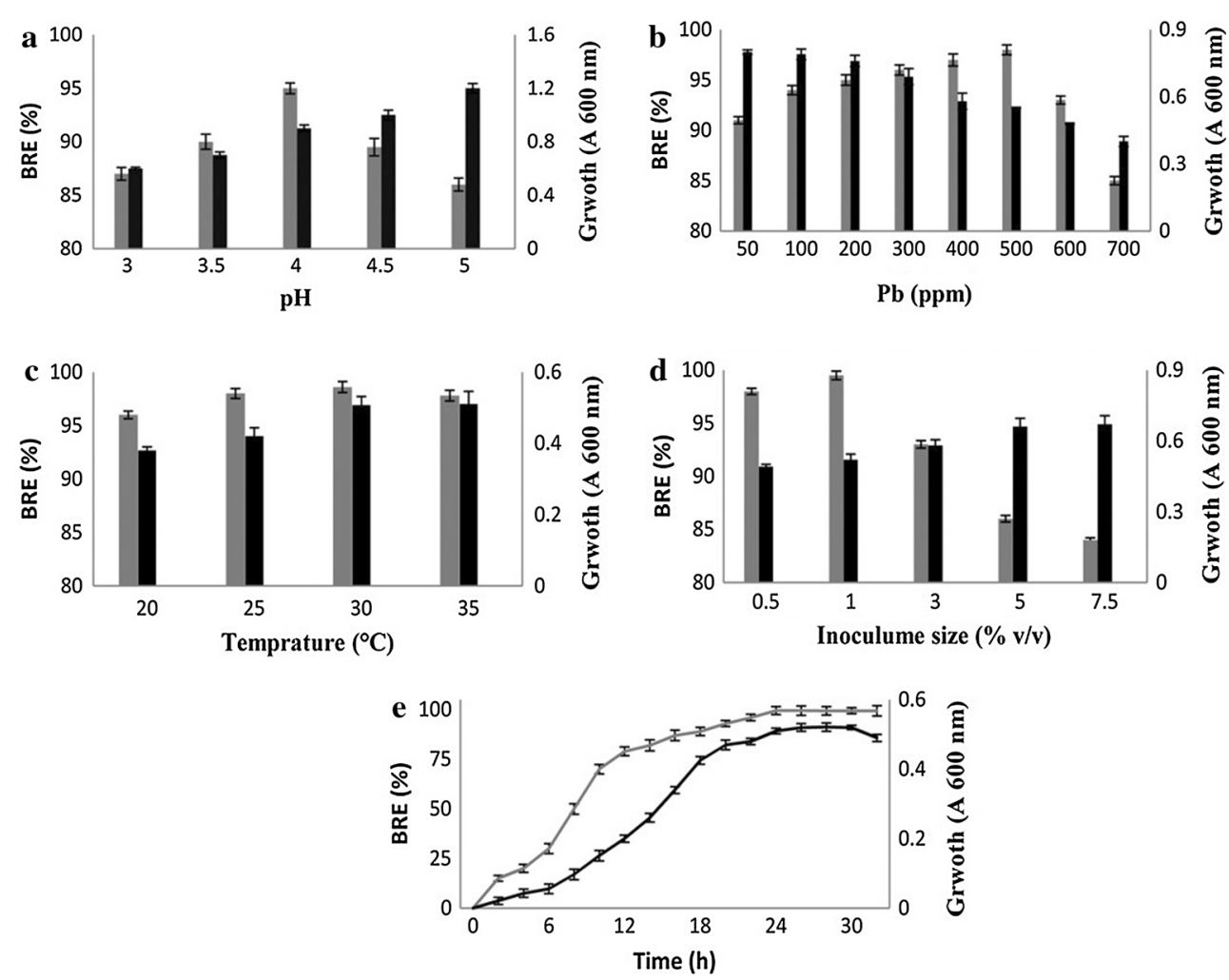

500, 600 and 700 ppm, respectively. However, increase in $\mathrm{Pb}$ concentration results in reduction of bacterial growth. The corresponding performances of removal capacity were $(\mathrm{mg} / \mathrm{g}): 7.0,14.2,28.8,43.6,58.8,73.5,84.1$ and 80.0 at a mentioned concentration of $\mathrm{Pb}$, respectively (Fig. 2b). For removal efficiency, the highest bioremediation rate was observed at $500 \mathrm{ppm} \mathrm{Pb}$ concentration and was applied for further experiments. It could be explained that at low metal concentration, the biosorption of the biosorbents is not fully utilized. In contrast, the existence of infinite heavy metal concentration reduces the efficiency due to toxicity towards cells. Figure 2c represents the BRE amounts for strain AS2 as 96, 98.2, 98.6 and $98 \%$ at temperature 20, 25, 30 and $35^{\circ} \mathrm{C}$, respectively, while the BRC were $(\mathrm{mg} /$ g): 73.0, 73.5, 73.9 and 73.9 at these temperatures, respectively. $\mathrm{Pb}$ removal was not different between 25 and $35{ }^{\circ} \mathrm{C}(p<0.05)$. However, environmental temperature (about $30^{\circ} \mathrm{C}$ ) is more desirable for in situ remediation process (Vijayaraghavan and Yun 2008) and was selected for further studies. Strain AS2 removed 98, 99.5, 93, 86 and $84 \%$ of the initial $\mathrm{Pb}$ at inoculum sizes (\% v/v) 0.5 , 1.0, 3.0, 5.0 and 7.0, respectively. The removal capacities for these variables were $(\mathrm{mg} / \mathrm{g}) 73.8,74.5,70.2,64.5$ and 63.3, respectively. The highest bioremediation rate was observed at the $1.0 \%(\mathrm{v} / \mathrm{v})$ inoculum size (Fig. 2d). As shown in Fig. 2e, by increasing the incubation time up to $24 \mathrm{~h}$, the amount of removal efficiency and capacity was increased, but incubation time more than $24 \mathrm{~h}$ did not affect the rate of remediation. Most remediation was observed in the mid-log cells.

\section{Role of active, inactive and EPS on $\mathrm{Pb}$ remediation/ SEM observation and EDS analysis}

Active cells showed the highest biological removal efficiency $(99.5 \%)$. The BRE amounts for autoclaved inactive cells, sodium azide inactive cells and EPS were 67, 63 and $87 \%$, respectively. A SEM image (Fig. 3) depicts $\mathrm{Pb}$ treated strain AS2 cells, indicating that the bacteria retain their shape and are visually unaffected after the $\mathrm{Pb}$

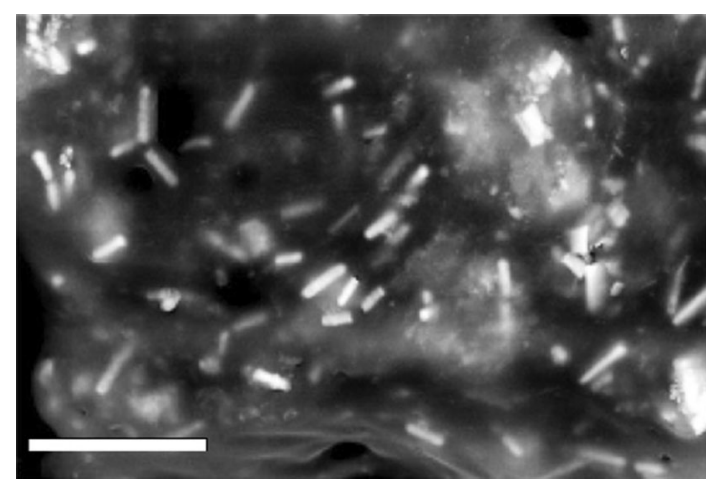

Fig. 3 Scanning electron microscopy of Pb-treated Bacillus species AS2. Bar $10 \mu \mathrm{m}$ 
treatment. The image demonstrated exopolysaccharide around the cells adhesion zone to trap the $\mathrm{Pb}$. EDS elemental analysis was carried out on bacterial cells before and after interaction with $\mathrm{Pb}$. Figure $4 \mathrm{a}$ depicts the spectrum of pure bacterial cells, and Fig. $4 \mathrm{~b}$ shows the presence of $\mathrm{Pb}$. Metal ion can be observed in $\mathrm{Pb}$-treated bacteria. Several mechanisms have been proposed to be involved in $\mathrm{Pb}$ biosorption: binding to phosphate, hydroxyl carbonyl and amino groups of peptidoglycan (Cabuk et al. 2006); teichoic acid and lipopolysaccharides (Beveridge and Fyfe 1985) of cell envelope; binding of toxic cation to extracellular polymers (like polysaccharides) (Pérez et al. 2008); precipitating $\mathrm{Pb}$ (II) inside/outside the cell in the form of an unusual phosphate compound $\mathrm{Pb}_{9}\left(\mathrm{PO}_{4}\right) 6$ (Naik and Dubey 2011); binding of $\mathrm{Pb}$ (II) by specific proteins like metallothioneins; and finally extracellular enzymes, such as superoxide dismutase, can also be engaged in $\mathrm{Pb}$ (II) biosorption (So et al. 2001). The dependence of $\mathrm{pH}$ as well as EDS analysis in our work indicates that ion exchange is probably at least partly responsible for the observed metal binding. However, involvement of EPS was also confirmed by SEM micrograph and the fact that $67 \%$ of the initial $\mathrm{Pb}$ could be absorbed in the cell-free polysaccharide extract. It was also hypothesized that $\mathrm{Pb}$ removal by strain AS2 is also an enzymatic dependent process, because the remediation rate decreased drastically in the inactive cells.

\section{Remediation of $\mathrm{Pb}$ from industrial waste}

Remediation of contaminated waste obtained from batteries and dye industries was analysed in a $1 \mathrm{~L}$ batch fermentation system. The concentration of $\mathrm{Pb}$ in these samples was as high as $1100 \mathrm{ppm}$. Twofold dilutions of these wastes were added to remediation culture at optimum condition. The bacterial
Fig. 4 Energy-dispersive X-ray analysis of non-treated (a) and treated (b) Bacillus species AS2

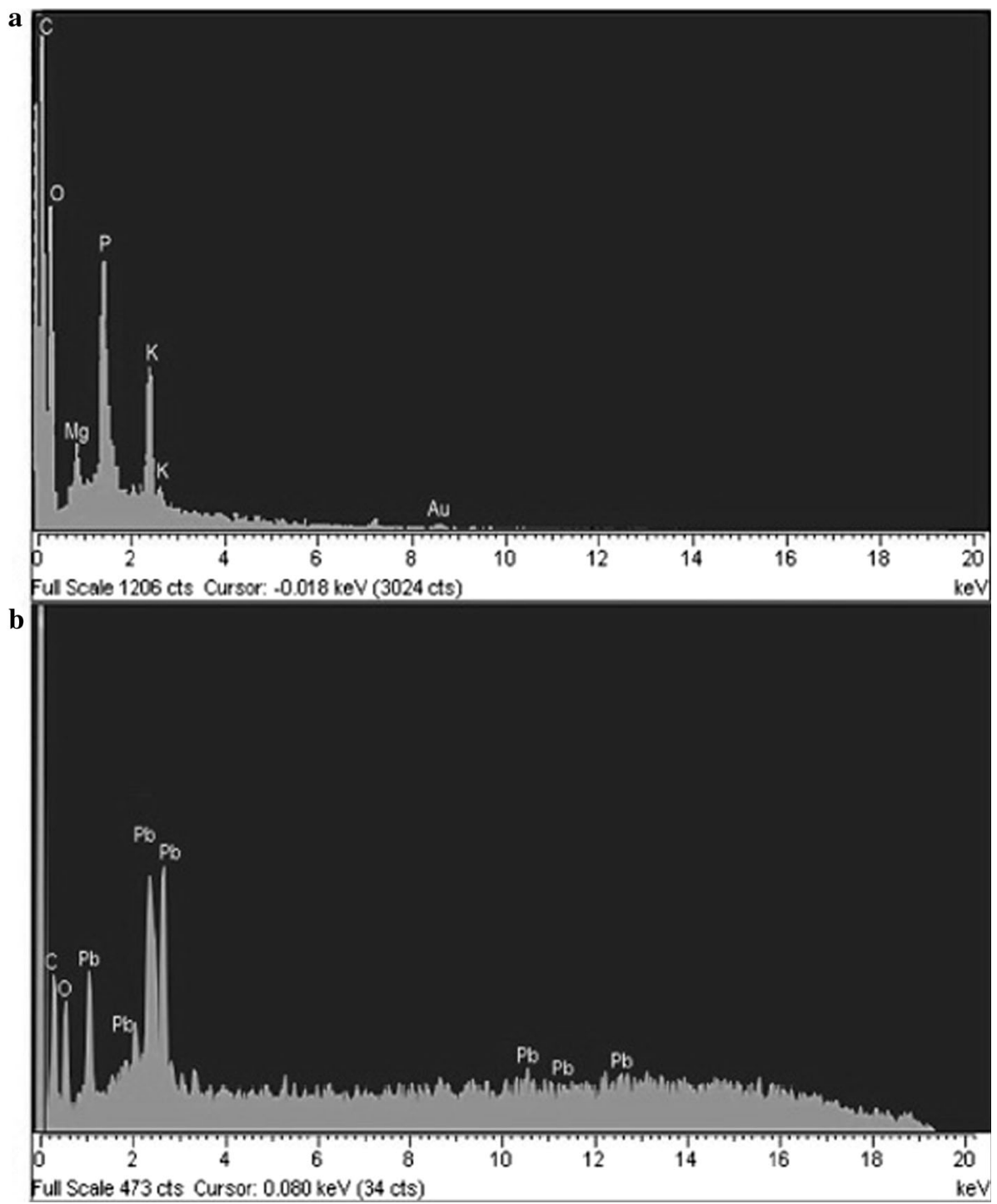


culture was able to reduce $500 \mathrm{ppm}$ initial $\mathrm{Pb}$ concentration to less than $10 \mathrm{ppm}$ (98.4\% removal efficiency) in $24 \mathrm{~h}$. High anthropogenic removal efficiency by the culture of this strain as well as more than $66 \%$ adsorption capacity appears to give desirable results for removal of $\mathrm{Pb}$ contamination from the environments.

\section{Identification of $\mathbf{P b}$-adsorbing bacteria}

The 16S rRNA gene sequences of strain AS2 were obtained (GenBank/EMBL/DDBJ accession number KT943756). Gene sequence analysis revealed strain AS2 to be a member of the genus Bacillus. The closest relative of this strain was Bacillus sonorensis NBCR $101234^{\mathrm{T}}$, with a $16 \mathrm{~S}$ rRNA gene sequence similarity of $99.5 \%$.

\section{Conclusion}

A novel indigenous bacterium from geogenic contaminated site with very high resistance to $\mathrm{Pb}(3125 \mathrm{ppm})$ and high biosorption activity $(99.5 \%$ of initial $\mathrm{Pb}$ ) was isolated. This strain probably uptakes $\mathrm{Pb}$ via different pathways. $\mathrm{Pb}$ concentration, $\mathrm{pH}$ and inoculum size are the most effective variables on the remediation process. Anthropogenic $\mathrm{Pb}$ removal by the culture of this strain resulted in more than $98.4 \%$ remediation of the initial $\mathrm{Pb}$. Application of this strain with more than $66 \%$ adsorption capacity appears to give desirable results for removal of $\mathrm{Pb}$ contamination from the environments.

Acknowledgments This work was supported by grant from Ferdowsi University of Mashhad (23889/3).

\section{References}

Batta N, Subudhi S, Lal B, Devi A (2013) Isolation of a lead tolerant novel bacterial species, Achromobacter sp. TL-3: assessment of bioflocculant activity. Indian J Exp Biol 51:1004-1011

Beveridge TJ, Fyfe WS (1985) Metal fixation by bacterial cell walls. Can J Earth Sci 22:1892-1898

Bhakta JN, Munekage Y, Ohnishi K, Jana BB (2012) Isolation and identification of cadmium- and lead-resistant lactic acid bacteria for application as metal removing probiotic. Int J Environ Sci Technol 9:433-440

Cabuk A, Akar T, Tunali S, Tabak O (2006) Biosorption characteristics of Bacillus sp. ATS-2 immobilized in silica gel for removal of $\mathrm{Pb}(\mathrm{II})$. J Hazard Mater 136:317-323

Chen C, Wang J (2007) Response of Saccharomyces cerevisiae to lead ion stress. Appl Microbiol Biotechnol 74:683-687

Chen QY, Luo Z, Hills C, Xue G, Tyrer M (2009) Precipitation of heavy metals from wastewater using simulated flue gas: sequent additions of fly ash, lime and carbon dioxide. Water Res 43:2605-2614

Deng LP, Su YY, Su H, Wang XT, Zhu XB (2007) Sorption and desorption of lead (II) from wastewater by green algae Cladophora fascicularis. J Hazard Mater 143:220-225
Gabr RM, Hassan SHA, Shoreit AAM (2008) Biosorption of lead and nickel by living and non-living cells of Pseudomonas aeruginosa ASU 6a. Int Biodeterior Biodegrad 62:195-203

Halttunen T, Salminen S, Tahvonen R (2007) Rapid removal of lead and cadmium from water by specific lactic acid bacteria. Int J Food Microbiol 114:30-35

Hasnain S, Yasmin S, Yasmin A (1993) The effects of lead resistant Pseudomonads on the growth of Triticum aestivum seedlings under lead stress. Environ Pollut 81:179-184

Hu Q, Qi HY, Zeng JH, Zhang HX (2007) Bacterial diversity in soils around a lead and zinc mine. J Environ Sci 19:74-79

Ismail Z, Salim K, Othman SZ, Ramli AH, Shirazi SM, Karim R, Khoo SY (2013) Determining and comparing the levels of heavy metal concentrations in two selected urban river water. Measurement 46:4135-4144

Jarosławiecka A, Piotrowska-Seget Z (2014) Lead resistance in micro-organisms. Microbiology 160:12-25

Johnson KJ, Ams DA, Wedel AN, Szymanowski JES, Weber DL, Schneegurt MA, Fein JB (2007) The impact of metabolic state on Cd adsorption onto bacterial cells. Geobiology 5:211-218

Kabbashi NA, Atieh MA, Al-Mamun A, Mirghami MES, Alam MDZ, Yahya N (2009) Kinetic adsorption of application of carbon nanotubes for $\mathrm{Pb}(\mathrm{II})$ removal from aqueous solution. J Environ Sci 21:539-544

Landaburu-Aguirre J, García V, Pongrácz E, Keiski RL (2009) The removal of zinc from synthetic wastewaters by micellarenhanced ultrafiltration: statistical design of experiments. Desalination 240:262-269

Lane DJ, Pace B, Olsen GJ, Stahl DA, Sogin ML, Pace NR (1985) Rapid determination of $16 \mathrm{~S}$ ribosomal RNA sequences for phylogenetic analyses. Proc Natl Acad Sci USA 82:6955-6959

Leung WC, Chua H, Lo W (2001) Biosorption of heavy metals by bacteria isolated from activated sludge. Appl Biochem Biotechnol 91:171-184

Li L, Liu H, Shi Z, Wang G (2013) Sphingobium cupriresistens sp. nov., a copper-resistant bacterium isolated from copper mine soil, and emended description of the genus Sphingobium. Int J Syst Evol Microbiol 63:604-609

Macek T, Mackova M (2011) Potential of biosorption technology. In: Kotrba P, Mackova M, Macek T (eds) Microbial biosorption of metals. Springer, London, pp 1-17

Maiti SK (2004) Handbook of Methods in Environmental Studies Vol. 1: Water and Wastewater Analysis, 2nd edn. ABD Publishers

Naik MM, Dubey SK (2011) Lead-enhanced siderophore production and alteration in cell morphology in a Pb-resistant Pseudomonas aeruginosa strain 4EA. Curr Microbiol 62:409-414

Naseem R, Tahir SS (2001) Removal of Pb (ii) from aqueous/acidic solutions by using bentonite as an adsorbent. Water Res 16:3982-3986

Pérez MPJA, García-Ribera R, Quesada T, Aguilera M, RamosCormenzana A, Monteoliva-Sánchez M (2008) Biosorption of heavy metals by the exopolysaccharide produced by Paenibacillus jamilae. World J Microbiol Biotechnol 24:2699-2704

Piotrowska-Seget Z, Cycoń M, Kozdrój J (2005) Metal-tolerant bacteria occurring in heavily polluted soil and mine spoil. Appl Soil Ecol 28:237-246

Pümpel T, Pernfub B, Pigher B, Diels L, Schinner F (1995) A rapid screening method for the isolation of metal-accumulating microorganisms. J Ind Microbiol 14:213-217

Roane TM, Kellogg ST (1996) Characterization of bacterial communities in heavy metal contaminated soils. Can J Microbiol 42:593-603

Saad B, Pok FW, Sujari ANA, Saleh MI (1998) Analysis of anions and cations in drinking water samples by Capillary Ion Analysis. Food Chem 61:249-254 
Sağ Y, Özer D, Kutsal T (1995) A comparative study of the biosorption of lead (II) ions to Z. ramigera and $R$. arrhizus. Process Biochem 30:169-174

So NW, Rho JY, Lee SY, Hancock IC, Kim JH (2001) A leadabsorbing protein with superoxide dismutase activity from Streptomyces subrutilus. FEMS Microbiol Lett 194:93-98

Sparks DL (2005) Toxic metals in the environment: the role of surfaces. Elements 1:193-197

Sun F, Shao Z (2007) Biosorption and bioaccumulation of lead by Penicillium sp. Psf-2 isolated from the deep sea sediment of the Pacific Ocean. Extremophiles 11:853-858

Trajanovska S, Britz ML, Bhave M (1997) Detection of heavy metal ion resistance genes in gram-positive and gram-negative bacteria isolated from a lead-contaminated site. Biodegradation 8:113-124

Vijayaraghavan K, Yun YS (2008) Bacterial biosorbents and biosorption. Biotechnol Adv 26:266-291
Zanardini E, Andreoni V, Borina S, Cappitellia F, Daffonchio D, Talottaa P, Sorlinia C, Ranallib G, Brunic S, Cariatic F (1997) Lead-resistant microorganisms from red stains of marble of the Certosa of Pavia, Italy and use of nucleic acid based techniques for their detection. Int Biodeter Biodegrad 40:171-182

Zhang J, Wang R, Jiang P, Liu Z (2002) Production of an exopolysaccharide bioflocculant by Sorangium cellulosum. Lett Appl Microbiol 34:178-181

Zhang Q, Pan B, Zhang W, Pan B, Lv L, Wang X, Wu J, Tao X (2009) Selective removal of $\mathrm{Pb}(\mathrm{II}), \mathrm{Cd}(\mathrm{II})$, and $\mathrm{Zn}$ (II) ions from waters by an inorganic exchanger $\mathrm{Zr}\left(\mathrm{HPO}_{3} \mathrm{~S}\right)_{2}$. J Hazard Mater 170:824-828

Zhu H, Guo J, Chen M, Feng G, Yao Q (2012) Burkholderia dabaoshanensis sp. nov., a heavy-metal-tolerant bacteria isolated from Dabaoshan mining area soil in China. PLoS One 7:1-6 